\title{
Flavobacterium rivuli sp. nov., Flavobacterium subsaxonicum sp. nov., Flavobacterium swingsii sp. nov. and Flavobacterium reichenbachii sp. nov., isolated from a hard water rivulet
}

Correspondence

Erko Stackebrandt erko@dsmz.de

\author{
Zahid Ali, Sylvie Cousin, Anja Frühling, Evelyne Brambilla, \\ Peter Schumann, Yun Yang and Erko Stackebrandt
}

DSMZ-German Collection of Microorganisms and Cell Cultures GmbH, Inhoffenstr. 7B, 38124
Braunschweig, Germany
A recent assessment of the cultured microbial diversity of a hard water rivulet on the Western slopes of Harz Mountain, Germany (Brambilla et al., 2007; Cousin et al., 2008), resulted in the isolation and description of several novel species of the genera Flavobacterium (Cousin et al., 2007) and Pedobacter (Muurholm et al., 2007) and of proteobacterial genera as well as some novel genera

Abbreviations: NJ, Neighbour-joining; MALDI-TOF, matrix assisted laser desorption ionisation time-of-flight; ML, maximum-likelihood.

The GenBank/EMBL/DDBJ accession numbers for the 16S rRNA gene ?sequences for strains WB $3.3-2^{\top}$, WB $4.1-42^{\top}$, WB $2.3-68^{\top}$ and WB 3.2-61 ${ }^{\top}$ are AM934661, AM934666, AM934651 and AM177616, respectively.

A dendrogram based on MALDI-TOF is available as a supplementary figure with the online version of this paper.
(Stackebrandt et al., 2007, 2008; Verbarg et al., 2008). In a previous publication (Cousin et al., 2008), the phylogeny of 362 flavobacterial strains was analysed and the distinct position of four isolates was determined. In this communication, we characterize these strains and conclude that they represent novel species of the genus Flavobacterium.

The isolation of strains from Westerhöfer Bach hard water rivulet has been described previously by Brambilla et al. (2007). Following isolation on R2A medium, the strains were transferred and maintained on the same medium at $20{ }^{\circ} \mathrm{C}$. The same medium and temperature were used to grow the phylogenetically related type strains of the genus Flavobacterium that were used as references, Flavobacterium limicola DSM $15094^{\mathrm{T}}$ and Flavobacterium psychrophilum DSM $3660^{\mathrm{T}}$, and some other type strains, i.e. 
Flavobacterium saliperosum DSM $21664^{\mathrm{T}}$, Flavobacterium terrigena DSM $17934^{\mathrm{T}}$ and Flavobacterium xinjiangense DSM $19743^{\mathrm{T}}$.

The colony morphology of the novel isolates and reference strains was observed using a stereomicroscope on R2A (Difco), TSA (Caso), NA (Difco) agars and on Cytophaga agar [CY, medium M67 according to the DSMZ catalogue of strains (DSMZ, 2001)] after 1-3 days incubation at $20{ }^{\circ} \mathrm{C}$. Gram staining was performed using the aminopeptidase and $\mathrm{KOH}$ reactions. The presence of flagella was detected using Gray's method (Smibert \& Krieg, 1994). Cells were tested for oxidase (tetramethyl-p-phenyldiamine dihydrochloride test) and catalase $\left(\mathrm{H}_{2} \mathrm{O}_{2}\right.$ test $)$ activities. Flexirubin pigments and gliding motility were assessed as described by Bernardet et al. (2002). The temperature range and optimum for growth were determined using a temperature gradient incubator (model TN-3; Toyo Kagaku Sangyo Co) from 0 to $40{ }^{\circ} \mathrm{C}$ with $1{ }^{\circ} \mathrm{C}$ increments. Strains WB $3.3-2^{\mathrm{T}}, \mathrm{WB} 3.2-61^{\mathrm{T}}$ and $\mathrm{WB} \quad 4.1-42^{\mathrm{T}}$ were grown in R2A broth. As strain WB $2.3-68^{\mathrm{T}}$ did not grow in R2A broth, growth tests were performed in CY broth. Results were recorded after $48 \mathrm{~h}$ incubation. The optimal $\mathrm{pH}$ for growth was determined in buffered R2A broth at between $\mathrm{pH} 5.8$ and 8.4, at $0.2 \mathrm{pH}$ unit intervals. Strain WB 2.3-68 ${ }^{\mathrm{T}}$, cultured in buffered CY broth, grew only at $\mathrm{pH}$ 7.2. The salt tolerance range was observed in CY broth supplemented with $1-6 \%(\mathrm{w} / \mathrm{v}) \mathrm{NaCl}$, at $1 \%$ intervals. Microaerophily was tested by the candle jar method (Gerhardt et al., 1981). Anaerobic growth was assessed in the Anaerocult A mini gas pack system (Merck). The results of these tests are presented in the species descriptions.

Tests to determine the degradation of pectin and chitin (Sigma-Aldrich) (Reichenbach \& Dworkin, 1981b), alginate (Sigma-Aldrich) (West \& Colwell, 1984) (recorded after three weeks), casein (Reichenbach \& Dworkin, 1981a) and starch and L-tyrosine (Barrow \& Feltham, 1993) (recorded after one week) followed previously described procedures. Cellulose hydrolysis was determined by following the maceration of a cellulose (Whatman No. 1) strip $(1 \times 3 \mathrm{~cm})$ in carbohydrate-free R2A broth. Formation of $\mathrm{H}_{2} \mathrm{~S}$ from cysteine was tested according to Dye (1968). DNA hydrolysis was determined on DNA agar (Difco). Other physiological properties were investigated using the API ZYM and API 20NE systems (bioMérieux) and the GN MicroPlate system (Biolog), according to the manufacturers' instructions. API ZYM tests were recorded after $6 \mathrm{~h}$ incubation while API 20NE and GN MicroPlate tests were read after $48 \mathrm{~h}$. All systems were incubated at $20{ }^{\circ} \mathrm{C}$. The results of the reactions are recorded in Table 1.

The methods used for DNA extraction and sequencing of the almost complete 16S rRNA gene were as described by Cousin et al. (2008). For phylogenetic analysis, the Flavobacterium database of the 'All-species living tree' was used (http://www.arb-silva.de/projects/living-tree/). The sequences of the novel isolates and of Flavobacterium lindanitolerans $\mathrm{IP}-10^{\mathrm{T}}$, Flavobacterium anhuiense KCTC $22128^{\mathrm{T}}$, Flavobacterium flevense DSM $1076^{\mathrm{T}}$ and Flavobacterium pectinovorum DSM $6368^{\mathrm{T}}$, which were not included in this database, were added and aligned by using the remote SINA aligner. The complete tree of type strains and novel isolates was then recalculated for the isolates and a selection of neighbouring type strains. Neighbour-joining (NJ) and maximum-likelihood (ML) analyses, as well as bootstrap calculations (with 1000 resamplings) were performed using the respective files in the ARB program (http://www.arb-home.de/). All of the novel strains showed $98.2 \%$ or less sequence similarity with type strains of members of the genus Flavobacterium. A sequence similarity value of $96.3 \%$ was found between strains WB $3.3-2^{\mathrm{T}}$ and $\mathrm{WB} \quad 4.1-42^{\mathrm{T}}$ and significantly lower similarity values were found with other members of the genus. Strains WB $3.2-61^{\mathrm{T}}$ and $\mathrm{WB} 2.3-68^{\mathrm{T}}$ were related to $F$. limicola DSM $15094^{\mathrm{T}}$ and F. psychrophilum DSM $3660^{\mathrm{T}}$, respectively (both with $98 \%$ sequence similarity). The isolated position of the four novel isolates was apparent in the dendrograms obtained using the NJ (Fig. 1) and the ML (identical branching patterns are indicated in Fig. 1) algorithms. Only a few branching points of the dendrogram were supported by high bootstrap values, which is consistent with published data (Brambilla et al., 2007).

The rrn operon heterogeneity of the isolates and reference strains was analysed by the Riboprinter microbial characterization system (Qualicon). Sample preparation and analysis were performed according to the manufacturer's instructions using the restriction enzyme $P v u \mathrm{II}$ as it is able to cut the rrn operon of Flavobacterium strains. EcoRI, conventionally used to cut DNA for RiboPrint analyses, did not result in discriminatory banding patterns. The band patterns were compared by using the BioNumerics software (Applied Maths). Clustering was performed by the unweighted pair group method with arithmetic means (UPGMA) based on the Pearson correlation coefficient, using an optimization coefficient of $1.2 \%$. Each ribopattern was obviously different, confirming that none of the new isolates was closely genomically related to any of the reference strains used (Fig. 2).

The mol\% G+C content of DNA was determined according to Mesbah et al. (1989). The G $+C$ contents of strains $\mathrm{WB} 2.3-68^{\mathrm{T}}$ and $\mathrm{WB} \quad 3.2-61^{\mathrm{T}}$ were 33.3 and $34.3 \mathrm{~mol} \%$, respectively. These values are consistent with those of recognized members of the genus Flavobacterium, which range from 30 to 37 mol\% (Bernardet et al., 1996; Van Trappen et al., 2003). The values for strains WB 3.3-2 ${ }^{\mathrm{T}}$ and $\mathrm{WB} 4.1-42^{\mathrm{T}}$, however, were 40.4 and $43.3 \mathrm{~mol} \%$, respectively, expanding the range reported for the genus by up to $5 \%$. As the latter two strains are obviously phylogenetic members of the genus Flavobacterium, the higher $\mathrm{mol} \% \mathrm{G}+\mathrm{C}$ of the DNA should not be used as an argument to exclude them from the genus. It might, however, be necessary to emend the genus description once further strains with higher than the above-mentioned range of DNA G $+\mathrm{C}$ content are included in the genus. 
Table 1. Differential biochemical properties of the four novel isolates and reference Flavobacterium type strains

Isolates WB 3.2-61 ${ }^{\mathrm{T}}$ and WB $2.3-68^{\mathrm{T}}$ are arranged next to their closest phylogenetic relative. Strains: 1 , WB 3.3-2 ${ }^{\mathrm{T}} ; 2$, WB $4.1-42^{\mathrm{T}}$; 3, WB 3.2-61 ${ }^{\mathrm{T}}$; 4 , F. limicola DSM $15094^{\mathrm{T}}$; 5, WB 2.3-68 $;$; 6, F. psychrophilum DSM $3660^{\mathrm{T}} ; 7$, F. saliperosum DSM $21664^{\mathrm{T}}$; $8 ;$ F. terrigena DSM $17934^{\mathrm{T}}$; 9 , F. xinjiangense DSM $19743^{\mathrm{T}}$. All data are from this study. All strains were positive for dextrin and L-glutamic acid utilization (GN MicroPlate). All strains were negative for hydrolysis of alginate, cellulose and pectin and L-tyrosine degradation and, according to API ZYM, for $\beta$-glucosidase, $\beta$ glucuronidase, lipase (C14), $\alpha$-mannosidase and $\alpha$-fucosidase activities; production of indole, fermentation of glucose, arginine dihydrolase and urease activities, and assimilation of mannitol, potassium gluconate, capric acid, adipic acid, malate, trisodium citrate, and phenylacetic acid (API 20NE); utilization of Tween 80, $\mathrm{N}$-acetyl-D-galactosamine, adonitol, D-arabitol, i-erythritol, myo-inositol, raffinose, D-sorbitol, cis-aconitic acid, citric acid, formic acid, D-galactonic acid lactone, D-gluconic acid, D-glucosaminic acid, $\alpha$-hydroxybutyric acid, $\beta$-hydroxybutyric acid, $\mathrm{p}$ hydroxyphenylacetic acid, itaconic acid, $\alpha$-ketoglutaric acid, malonic acid, propionic acid, quinic acid, D-saccharic acid, sebacic acid, succinic acid, bromosuccinic acid, succinamic acid, glucuronamide, L-alaninamide, D-alanine, L-histidine, L-phenylalanine, D-mannitol, xylitol, L-pyroglutamic acid, D-serine, phenylethylamine, putrescine, 2-aminoethanol, 2,3-butanediol, glycerol, DL- $\alpha$-glycerol phosphate, DL-carnitine, $\gamma$-aminobutyric acid, urocanic acid and inosine (GN MicroPlate). +, Positive; -, negative; w, weak positive; NG, no growth.

\begin{tabular}{|c|c|c|c|c|c|c|c|c|c|}
\hline Characteristic & 1 & 2 & 3 & 4 & 5 & 6 & 7 & 8 & 9 \\
\hline Casein & - & - & + & - & - & - & - & - & - \\
\hline Chitin & - & - & - & - & - & - & - & - & + \\
\hline DNA & - & - & $\mathrm{w}$ & NG & NG & NG & NG & NG & NG \\
\hline $\mathrm{H}_{2} \mathrm{~S}$ production & $\mathrm{W}$ & $\mathrm{W}$ & $\mathrm{W}$ & $\mathrm{W}$ & NG & $\mathrm{W}$ & + & W & NG \\
\hline Starch & + & + & + & - & - & - & - & W & + \\
\hline Tween 40 & + & + & + & NG & - & + & - & - & - \\
\hline Tween 80 & + & + & - & - & + & + & + & + & - \\
\hline \multicolumn{10}{|l|}{ API ZYM* } \\
\hline Acid phosphatase & 5 & 3 & 5 & 4 & 5 & 3 & 1 & 0 & 3 \\
\hline Alkaline phosphatase & 2 & 4 & 5 & 5 & 5 & 5 & 5 & 5 & 5 \\
\hline$\alpha$-Chymotrypsin & 0 & 0 & 2 & 0 & 5 & 0 & 0 & 0 & 0 \\
\hline Cystine arylamidase & 0 & 1 & 2 & 2 & 2 & 1 & 3 & 1 & 1 \\
\hline Esterase (C4) & 0 & 0 & 0 & 1 & 0 & 0 & 0 & 0 & 0 \\
\hline Esterase lipase (C8) & 1 & 1 & 1 & 1 & 2 & 1 & 1 & 0 & 1 \\
\hline$\alpha$-Galactosidase & 3 & 4 & 0 & 3 & 0 & 0 & 0 & 0 & 0 \\
\hline$\beta$-Galactosidase & 5 & 2 & 2 & 0 & 0 & 0 & 0 & 0 & 1 \\
\hline$\alpha$-Glucosidase & 0 & 2 & 5 & 5 & 0 & 0 & 0 & 0 & 4 \\
\hline Leucine arylamidase & 3 & 5 & 5 & 5 & 3 & 5 & 4 & 3 & 4 \\
\hline$N$-Acetyl- $\beta$-glucosaminidase & 0 & 0 & 3 & 5 & 0 & 0 & 5 & 0 & 5 \\
\hline Naphthol-AS-BI-phosphohydrolase & 4 & 2 & 5 & 4 & 3 & 1 & 1 & 1 & 3 \\
\hline Trypsin & 1 & 2 & 1 & 1 & 0 & 1 & 2 & 4 & 0 \\
\hline Valine arylamidase & 1 & 3 & 5 & 5 & 5 & 1 & 5 & 5 & 5 \\
\hline \multicolumn{10}{|l|}{ API $20 \mathrm{NE}$} \\
\hline$\beta$-Galactosidase & + & + & + & - & - & - & - & - & $\mathrm{w}$ \\
\hline \multicolumn{10}{|l|}{ Assimilation of: } \\
\hline$N$-Acetylglucosamine & - & - & + & - & - & - & - & - & - \\
\hline L-Arabinose & $\mathrm{w}$ & + & + & - & - & - & - & - & - \\
\hline D-Glucose & $\mathrm{w}$ & + & + & + & - & - & - & - & - \\
\hline Maltose & + & + & + & + & - & - & - & - & - \\
\hline D-Mannose & $\mathrm{w}$ & + & + & $\mathrm{w}$ & - & - & - & - & - \\
\hline \multicolumn{10}{|l|}{ GN MicroPlate (utilization of) } \\
\hline Acetic acid & + & - & - & - & - & - & - & - & - \\
\hline$N$-Acetyl-D-glucosamine & - & - & + & - & - & - & - & - & $\mathrm{w}$ \\
\hline L-Alanine & - & + & - & - & - & - & - & - & - \\
\hline L-Alanylglycine & + & + & $\mathrm{w}$ & + & - & - & + & - & + \\
\hline L-Arabinose & + & + & + & - & - & - & - & - & - \\
\hline L-Asparagine & - & - & + & + & - & - & - & - & - \\
\hline L-Aspartic acid & - & - & + & + & - & - & - & - & - \\
\hline Cellobiose & + & + & + & - & - & - & - & - & $\mathrm{w}$ \\
\hline$\alpha$-Cyclodextrin & + & + & + & + & - & - & - & - & + \\
\hline D-Fructose & + & + & + & - & - & - & - & - & $\mathrm{w}$ \\
\hline L-Fucose & - & + & $\mathrm{w}$ & - & - & - & - & - & - \\
\hline D-Galactose & + & + & - & - & - & - & - & - & - \\
\hline D-Galacturonic acid & - & - & + & - & - & - & - & - & - \\
\hline
\end{tabular}


Table 1. cont.

\begin{tabular}{|c|c|c|c|c|c|c|c|c|c|}
\hline Characteristic & 1 & 2 & 3 & 4 & 5 & 6 & 7 & 8 & 9 \\
\hline Gentiobiose & + & + & + & - & - & - & - & - & + \\
\hline$\alpha$-D-Glucose 1-phosphate & - & - & + & + & - & - & - & - & $\mathrm{w}$ \\
\hline$\alpha$-D-Glucose & + & + & + & + & - & - & - & - & + \\
\hline D-Glucuronic acid & - & - & + & - & - & - & - & - & - \\
\hline Glycyl-L-aspartic acid & - & + & + & + & - & - & - & - & + \\
\hline Hydroxy-L-proline & - & $\mathrm{w}$ & - & - & - & - & $\mathrm{w}$ & - & - \\
\hline$\alpha$-Ketobutyric acid & - & + & + & - & - & - & + & + & - \\
\hline$\alpha$-Ketovaleric acid & - & $\mathrm{w}$ & - & - & - & - & - & + & - \\
\hline DL-Lactic acid & - & + & - & - & - & - & - & - & - \\
\hline$\alpha$-D-Lactose & + & - & + & - & - & - & - & - & - \\
\hline Lactulose & + & $\mathrm{W}$ & - & - & - & - & - & - & - \\
\hline Methyl $\beta$-D-glucoside & - & + & - & - & - & - & - & - & $\mathrm{W}$ \\
\hline Methylpyruvate & + & + & + & + & - & - & $\mathrm{w}$ & - & w \\
\hline Monomethyl succinate & + & $\mathrm{w}$ & $\mathrm{W}$ & + & - & - & - & - & + \\
\hline L-Ornithine & - & + & + & + & - & + & $\mathrm{w}$ & - & $\mathrm{w}$ \\
\hline L-Proline & + & + & + & + & - & + & + & + & + \\
\hline D-Psicose & + & + & - & - & - & - & - & - & - \\
\hline L-Rhamnose & - & + & - & - & - & - & - & - & - \\
\hline L-Serine & - & + & - & + & - & - & - & - & - \\
\hline Sucrose & - & - & - & - & - & - & - & - & + \\
\hline L-Threonine & + & + & + & + & - & - & + & + & + \\
\hline Thymidine & - & - & - & - & - & - & + & - & - \\
\hline
\end{tabular}

${ }^{\star}$ Results are expressed as API ZYM scores: 0 , no activity; 1, lowest activity; 5, highest activity.

The preparation of cell extracts and handling of samples for matrix assisted laser desorption ionisation time-of-flight (MALDI-TOF) analyses were conducted as described by Cousin et al. (2008). Samples were analysed on a Microflex L20 MS (Bruker Daltonics) and BioTyper software, Version 1.0 (Bruker Daltonics) was used for processing the raw spectra and comparing spectra in order to classify the strains (Cousin et al., 2008). Spectra recorded with 16 replicates per strain were smoothed, their baselines were corrected and peak lists were generated automatically according to the parameter settings. The main spectra were created by extraction of the specific peak information from the individual spectra of a particular strain. Based on similarity scores of the main spectra, dendrograms were constructed showing the clustering of strains by their mass spectra. As the correlation between dendrograms based on MALDI-TOF protein patterns and $16 \mathrm{~S}$ rRNA gene sequence similarities is high only at the intra-specific level (Cousin et al., 2008), lack of correlation between the relevant patterns of type strains was not surprising. Only the clustering of $F$. psychrophilum DSM $3660^{\mathrm{T}}$ and strain WB $2.3-68^{\mathrm{T}}$ was confirmed (see Supplementary Fig. S1 available in IJSEM online) while the other isolates were distinctly apart from all the Flavobacterium type strains.

Some of the reactions in the API ZYM system were positive for all strains investigated though with varying degrees of activity (Table 1 ). Of the new isolates, strain WB $2.3-68^{\mathrm{T}}$ appeared less active and this restricted activity was shared by its closest relatives, F. psychrophilum DSM $3660^{\mathrm{T}}$, F. saliperosum DSM $21664^{\mathrm{T}}$ and F. terrigena DSM $17934^{\mathrm{T}}$. In addition, according to the API 20NE and GN MicroPlate systems, isolates WB $3.3-2^{\mathrm{T}}$, WB $4.1-42^{\mathrm{T}}$ and WB $3.2-61^{\mathrm{T}}$ were metabolically more versatile than strain WB $2.3-68^{\mathrm{T}}$ and the reference strains, except for $F$. xinjiangense DSM $19743^{\mathrm{T}}$. The phylogenetic neighbours strains WB $3.3-2^{\mathrm{T}}$ and WB $4.1-42^{\mathrm{T}}$ shared many positive reactions, mainly for carbohydrate assimilation, but they differed in several other reactions. Likewise, strains $\mathrm{WB} 3.2-61^{\mathrm{T}}$ and F. limicola 


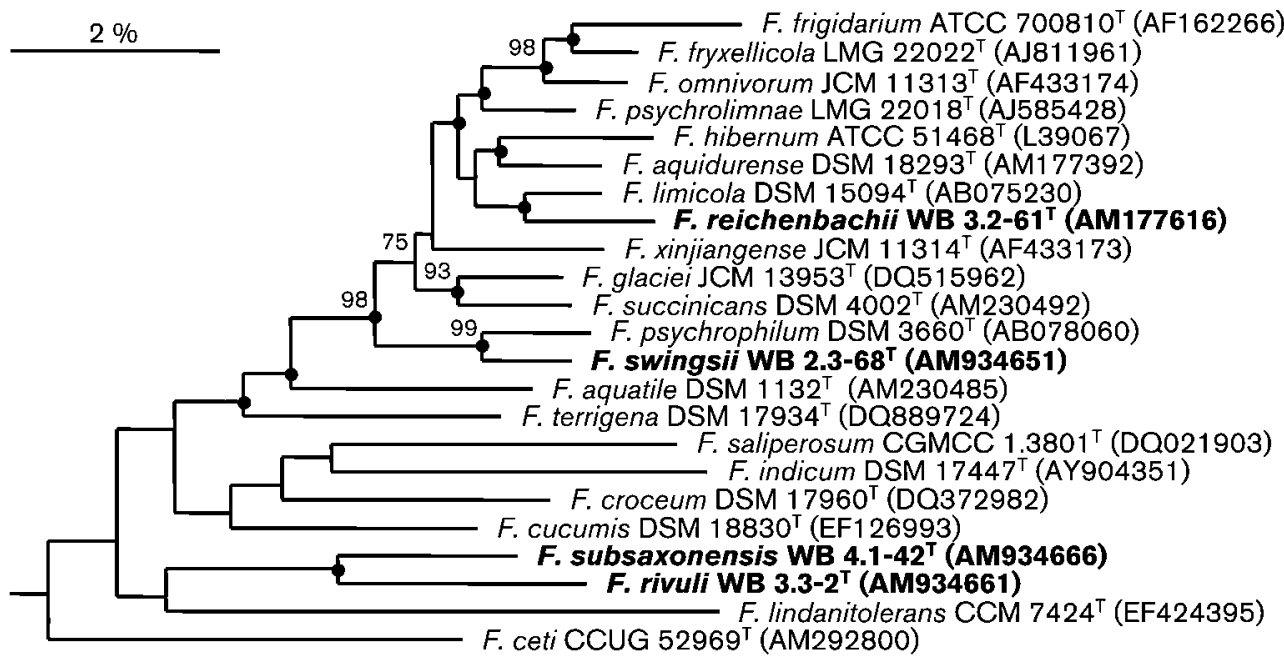

Fig. 1. Neighbour-joining phylogenetic tree based on 16S rRNA gene sequences showing the relationship of strains WB 3.2$61^{\top}$, WB $2.3-68^{\top}$, WB $4.1-42^{\top}$ and WB $3.3-2^{\top}$ and neighbouring Flavobacterium type strains. Branching points which are identical with those of the maximum-likelihood tree are indicated by filled circles. Numbers at branching points are bootstrap values $>70 \%$ (1000 resamplings). Bar, $2 \%$ sequence divergence. Terrimonas ferruginea DSM $30193^{\top}$ (GenBank accession no. AM230484) served as a root (not shown).

DSM $15094^{\mathrm{T}}$ shared several common reactions, notably for the assimilation of amino acids, which were often different from those of the above-mentioned strain pair. All four new isolates could be unambiguously differentiated from each other and from the reference type strains.

Fatty acid analysis was performed according to Miller (1982) on the isolates and reference strains grown on R2A agar at $20{ }^{\circ} \mathrm{C}$ for 3 days. R2A agar was selected as strains WB 2.3$68^{\mathrm{T}}$, F. psychrophilum DSM $3660^{\mathrm{T}}$ and F. terrigena DSM $17934^{\mathrm{T}}$ did not grow within $24-72 \mathrm{~h}$ on trypticase soy agar
(TSA; Difco), the medium recommended by the Microbial Identification System (MIDI: Microbial ID). Fatty acid analysis was performed following the standard protocol of the MIDI system. Extracts were analysed in a GC (model HP6890A; Hewlett Packard) equipped with a flame-ionization detector (Kämpfer \& Kroppenstedt, 1996). In all strains studied, the major constituents, though in varying quantities, included iso- $\mathrm{C}_{15: 1}$, iso- $\mathrm{C}_{15: 0}$, iso- $\mathrm{C}_{15: 0} 3-\mathrm{OH}$, iso- $\mathrm{C}_{17: 0} 3-$ $\mathrm{OH}$ and summed feature 3 (comprising $\mathrm{C}_{16: 1} \omega 7 \mathrm{c}$ and/or iso$\mathrm{C}_{15: 0}$ 2-OH) (Table 2). However, strains WB $3.2-61^{\mathrm{T}}$ and WB $2.3-68^{\mathrm{T}}$ contained significant amounts of iso- $\mathrm{C}_{17: 1} \omega 9 c$,

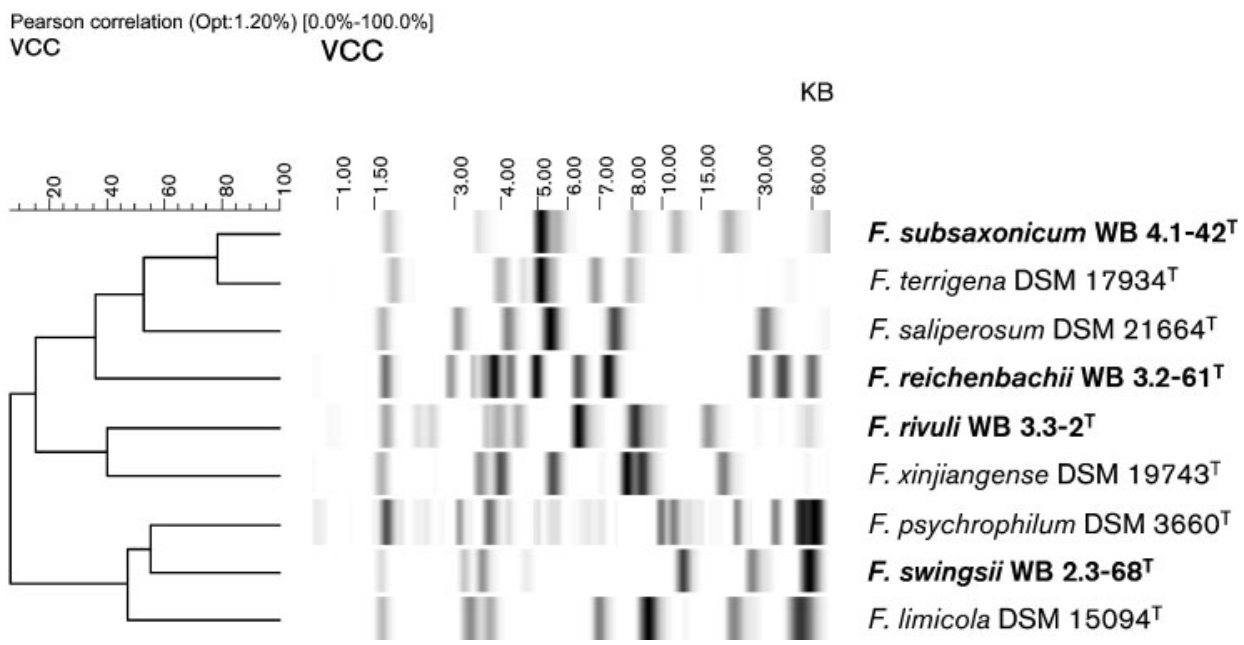

Fig. 2. Pvull restriction pattern ribotypes of the four novel isolates and type strains of reference Flavobacterium taxa. Analysis was performed with the Riboprinter microbial characterization system (Qualicon). 
Table 2. Fatty acid profile (\%) of the four novel isolates and type strains of reference Flavobacterium species grown on R2A agar Isolates WB 3.2-61 ${ }^{\mathrm{T}}$ and WB $2.3-68^{\mathrm{T}}$ are arranged next to their closest phylogenetic relative. Strains: $1, \mathrm{WB} 3.3-2^{\mathrm{T}} ; 2$, WB $4.1-42^{\mathrm{T}} ; 3, \mathrm{WB}^{2} .2-61^{\mathrm{T}}$; 4 , F. limicola DSM $15094^{\mathrm{T}}$; 5, WB 2.3-68 ${ }^{\mathrm{T}}$; 6, F. psychrophilum DSM $3660^{\mathrm{T}}$; 7, F. saliperosum DSM $21664^{\mathrm{T}}$; 8 , F. terrigena DSM $17934^{\mathrm{T}}$; 9 , F. xinjiangense DSM $19743^{\mathrm{T}}$. All data are from this study. Fatty acids amounting to $\leqslant 1 \%$ of the total fatty acids in all strains studied are omitted. ND, Not detected; $\operatorname{tr}$, trace $(<1 \%$ of total).

\begin{tabular}{|c|c|c|c|c|c|c|c|c|c|}
\hline Fatty acid & 1 & 2 & 3 & 4 & 5 & 6 & 7 & 8 & 9 \\
\hline iso- $\mathrm{C}_{14: 0}$ & ND & ND & $\operatorname{tr}$ & 4.2 & $\operatorname{tr}$ & $\operatorname{tr}$ & $\operatorname{tr}$ & $\operatorname{tr}$ & 3.9 \\
\hline iso- $\mathrm{C}_{15: 1}$ & 4.3 & 2.9 & 7.0 & 3.5 & 11.8 & 13.9 & 8.2 & 12.4 & 2.4 \\
\hline anteiso- $\mathrm{C}_{15: 0}$ & 5.6 & 8.5 & 4.3 & 5.4 & $\operatorname{tr}$ & 2.4 & 5.1 & 2.2 & 3.3 \\
\hline $\mathrm{C}_{15: 1} \omega 6 c$ & $\operatorname{tr}$ & $\operatorname{tr}$ & 6.5 & 8.5 & 7.0 & 11.0 & 2.5 & 3.1 & 11.5 \\
\hline $\mathrm{C}_{15: 0}$ & 4.3 & 3.1 & 12.4 & 6.9 & 23.0 & 10.3 & 13.5 & 12.3 & 12.1 \\
\hline iso- $\mathrm{C}_{16: 0}$ & 1.3 & 1.5 & 1.7 & 9.7 & 1.3 & 1.0 & 8.7 & 6.6 & 6.9 \\
\hline $\mathrm{C}_{16: 0}$ & 8.8 & 9.4 & 1.9 & 1.7 & $\operatorname{tr}$ & $\operatorname{tr}$ & $\operatorname{tr}$ & 1.5 & 2.1 \\
\hline iso- $\mathrm{C}_{15: 0} 3-\mathrm{OH}$ & 3.9 & 3.7 & 8.8 & 4.1 & 9.2 & 7.7 & 4.0 & 5.1 & 4.3 \\
\hline iso- $\mathrm{C}_{17: 1} \omega 9 c$ & 1.4 & $\operatorname{tr}$ & 3.8 & 3.0 & 7.8 & 10.0 & 17.0 & $\operatorname{tr}$ & 2.2 \\
\hline $\mathrm{C}_{15: 0} 3-\mathrm{OH}$ & ND & $\mathrm{ND}$ & 2.2 & $\operatorname{tr}$ & 1.5 & ND & $\operatorname{tr}$ & $\operatorname{tr}$ & $\operatorname{tr}$ \\
\hline $\mathrm{C}_{17: 1} \omega 8 c$ & $\mathrm{ND}$ & ND & $\operatorname{tr}$ & $\operatorname{tr}$ & 2.0 & $\operatorname{tr}$ & 1.5 & $\operatorname{tr}$ & $\operatorname{tr}$ \\
\hline iso- $\mathrm{C}_{17: 0} 3-\mathrm{OH}$ & 5.2 & 7.8 & 9.8 & 4.5 & 11.8 & 8.6 & 7.3 & 10.1 & 5.0 \\
\hline $\mathrm{C}_{17: 0} 2-\mathrm{OH}$ & 1.7 & 2.5 & 1.0 & $\operatorname{tr}$ & ND & $\mathrm{ND}$ & 1.6 & $\operatorname{tr}$ & $\operatorname{tr}$ \\
\hline Summed feature $3^{\star}$ & 35.1 & 20.7 & 8.1 & 11.1 & 2.2 & 1.6 & 1.8 & 4.1 & 14.2 \\
\hline
\end{tabular}

${ }^{\star}$ Summed features are groups of two or three fatty acids that cannot be separated by GLC using the MIDI System. Summed feature 3 comprised $\mathrm{C}_{16: 1} \omega 7 c$ and/or iso- $\mathrm{C}_{15: 0} 2-\mathrm{OH}$.

as was also the case for $F$. limicola DSM $15094^{\mathrm{T}}, F$. psychrophilum DSM $3660^{\mathrm{T}}$ and $F$. saliperosum DSM $21664^{\mathrm{T}}$. Strains WB $3.2-61^{\mathrm{T}}$ and WB $2.3-68^{\mathrm{T}}$ also contained a higher percentage of $\mathrm{C}_{15: 0}$ and iso- $\mathrm{C}_{15: 0} 3-\mathrm{OH}$ in comparison with all of the five Flavobacterium type strains tested. Strains WB 3.3-2 $2^{\mathrm{T}}$ and $\mathrm{WB} 4.1-42^{\mathrm{T}}$ showed the highest percentage of $\mathrm{C}_{16: 0}$ and summed feature 3 compared with all other strains. The fatty acid patterns of the six strains that were able to grow on TSA differed from those of the same strains grown on $\mathrm{R} 2 \mathrm{~A}$ due to the absence of $\mathrm{C}_{15: 0}$; the other main components were present, though in different proportions (data not shown). The fatty acid compositions reported in the original descriptions of some of the reference strains studied essentially agreed with those obtained in this study, although the growth medium was either not specified (Tamaki et al., 2003) or different (Zhu et al., 2003; Wang et al., 2006). For example, F. saliperosum reportedly lacked summed feature 3 , iso- $\mathrm{C}_{17: 0} 3-\mathrm{OH}$, iso- $\mathrm{C}_{16: 0}$ and iso- $\mathrm{C}_{15: 0}$ 3-OH (Wang et al., 2006).

The 16S rRNA gene sequence similarities of $\leqslant 98 \%$ among the four novel isolates and between them and all Flavobacterium type strains demonstrated that they belong to unique genospecies (Stackebrandt \& Ebers, 2006). It was therefore not necessary to determine the level of DNADNA hybridization. The genomic distinctiveness is corro- borated by distinct rrn operon patterns and MALDI-TOF patterns of whole-cell extracts to which ribosomal proteins contribute significantly. Chemotaxonomically, the four novel isolates show a subset of fatty acids that confirm their affiliation to the genus Flavobacterium; the other fatty acids, however, show sufficient qualitative and quantitative differences to allow their identification. As the cultural and metabolic properties support the uniqueness of the new isolates, it is suggested that the isolates represent four novel species of the genus Flavobacterium for which the following names are proposed: Flavobacterium rivuli for strain WB 3.3-2 $2^{\mathrm{T}}$, Flavobacterium subsaxonicum for strain $\mathrm{WB}$ 4.1-42 ${ }^{\mathrm{T}}$, Flavobacterium swingsii for strain WB $2.3-68^{\mathrm{T}}$ and Flavobacterium reichenbachii for strain WB $3.2-61^{\mathrm{T}}$.

\section{Description of Flavobacterium rivuli sp. nov.}

Flavobacterium rivuli (ri'vu.li. L. gen. n. rivuli of/from a small river).

Gram-staining-negative ( $\mathrm{KOH}$ and aminopeptidase reactions positive), aerobic and microaerobic rods (0.4$0.6 \times 1.5-2.5 \mu \mathrm{m})$. Does not grow anaerobically. Growth occurs between 4 and $29{ }^{\circ} \mathrm{C}$ with an optimal temperature between 16 and $24{ }^{\circ} \mathrm{C}$. Growth between 4 and $8{ }^{\circ} \mathrm{C}$ is sparse; no growth occurs below $4{ }^{\circ} \mathrm{C}$ or above $29{ }^{\circ} \mathrm{C}$. Growth occurs 
between $\mathrm{pH} 6.4$ and 7.8 with an optimal pH of 7.0. Growth occurs at $\mathrm{NaCl}$ concentrations between 0 and $2 \%(\mathrm{w} / \mathrm{v})$ with optimal growth at $1 \%(\mathrm{w} / \mathrm{v}) \mathrm{NaCl}$. Gliding motility and flagella are absent. Colonies on R2A, NA, TSA and CY agars are circular with entire margins, convex, smooth, translucent, soft and butyrous. Colonies are pearl white on R2A and CY agars and yellow on TSA and NA agars. Colonies are 2-2.5 mm in diameter on R2A agar and $0.3-0.8 \mathrm{~mm}$ on NA, TSA and CY agars. Flexirubin pigments are absent. Catalaseand oxidase-positive. Nitrate reduction is negative. Aesculin and glycogen hydrolysis are positive; cellulose (Whatman No. 1), chitin and gelatin hydrolysis are negative. Other physiological reactions are given in Table 1 . The major fatty acids $\left(>7.5 \%\right.$ of total) are iso- $\mathrm{C}_{15: 0}, \mathrm{C}_{16: 0}$ and summed feature 3 (comprising $\mathrm{C}_{16: 1} \omega 7 c$ and/or iso- $\mathrm{C}_{15: 0} 2-\mathrm{OH}$ ).

The type strain, WB $3.3-2^{\mathrm{T}} \quad\left(=\mathrm{DSM} \quad 21788^{\mathrm{T}}=\mathrm{CIP}\right.$ $\left.109865^{\mathrm{T}}\right)$, was isolated from a spring of Westerhöfer Bach, Westerhof, $40 \mathrm{~km}$ north of Göttingen, Germany. The DNA $\mathrm{G}+\mathrm{C}$ content of the type strain is $40.4 \mathrm{~mol} \%$.

\section{Description of Flavobacterium subsaxonicum sp. nov.}

Flavobacterium subsaxonicum (sub.sa.xo'ni.cum. L. prep. sub low, below, under; L. adj. saxonicus pertaining to Saxony; N.L. neut. adj. subsaxonicum pertaining to Lower Saxony).

Gram-staining-negative ( $\mathrm{KOH}$ and aminopeptidase reactions positive), aerobic and microaerobic rods $(1.5 \times 3.5-4.5 \mu \mathrm{m})$. Does not grow anaerobically. Growth occurs between 2 and $38{ }^{\circ} \mathrm{C}$ with an optimal temperature between 24 and $28{ }^{\circ} \mathrm{C}$. Growth between 2 and $9{ }^{\circ} \mathrm{C}$ is sparse; no growth occurs below $2{ }^{\circ} \mathrm{C}$ or above $38{ }^{\circ} \mathrm{C}$. Growth occurs between $\mathrm{pH} 7.0$ and 7.6 with optimal $\mathrm{pH}$ of 7.2. Growth occurs at $\mathrm{NaCl}$ concentrations between 0 and $2 \%(\mathrm{w} / \mathrm{v})$ with optimal growth at $0 \%$ $(\mathrm{w} / \mathrm{v}) \mathrm{NaCl}$. Gliding motility and flagella are absent. Colonies on R2A, NA, TSA and CY agars are circular with entire margins, convex, smooth, opaque, soft and butyrous. Colonies are light yellow on R2A, NA and TSA agars and pearl white on $\mathrm{CY}$ agar. Colonies are $0.8-1 \mathrm{~mm}$ in diameter on R2A agar and $0.2-0.3 \mathrm{~mm}$ on $\mathrm{CY}$ agar. Flexirubin pigments are present. Catalase- and oxidase-positive. Nitrate reduction is negative. Aesculin, gelatin and glycogen hydrolysis are positive; cellulose (Whatman No. 1) and chitin hydrolysis are negative. Other physiological reactions are given in Table 1 . The major fatty acids $(>7.5 \%$ of total) are iso- $\mathrm{C}_{15: 0}$, anteiso- $\mathrm{C}_{15: 0}, \mathrm{C}_{16: 0}$, iso- $\mathrm{C}_{17: 0} 3-\mathrm{OH}$ and summed feature 3 (comprising $\mathrm{C}_{16: 1} \omega 7 \mathrm{c}$ and/or iso- $\mathrm{C}_{15: 0} 2-\mathrm{OH}$ ).

The type strain, WB $4.1-42^{\mathrm{T}} \quad\left(=\mathrm{DSM} \quad 21790^{\mathrm{T}}=\mathrm{CIP}\right.$ $109867^{\mathrm{T}}$ ), was isolated from a spring of Westerhöfer Bach, Westerhof, $40 \mathrm{~km}$ north of Göttingen, Germany. The DNA $\mathrm{G}+\mathrm{C}$ content of the type strain is $43.3 \mathrm{~mol} \%$.

\section{Description of Flavobacterium swingsii sp. nov.}

Flavobacterium swingsii (swing'si.i. N.L. masc. gen. n. swingsii of Swings, named after Jean Swings, a famous
Belgian microbiologist and former President of the World Federation of Culture Collections).

Gram-staining-negative ( $\mathrm{KOH}$ and aminopeptidase reactions positive), aerobic and microaerobic rods $(0.3 \times 4.5-$ $6.0 \mu \mathrm{m})$. Does not grow anaerobically. Growth occurs between 3 and $26{ }^{\circ} \mathrm{C}$ with an optimal temperature between 24 and $26{ }^{\circ} \mathrm{C}$. Growth between 3 and $8{ }^{\circ} \mathrm{C}$ is sparse; no growth occurs below $3{ }^{\circ} \mathrm{C}$ or above $26{ }^{\circ} \mathrm{C}$. Growth occurs at $\mathrm{pH} 7.0$ (tested on R2A agar). Growth occurs with $0 \%$ (w/v) $\mathrm{NaCl}$; no growth occurs with $1 \%(\mathrm{w} / \mathrm{v}) \mathrm{NaCl}$. Gliding motility and flagella are absent. Colonies on R2A and $\mathrm{CY}$ agars are yellow and $0.4-0.5 \mathrm{~mm}$ in diameter, circular with entire margins, convex, smooth, translucent, sticky and butyrous. Growth on NA agar is poor and no growth occurs on TSA agar or in R2A broth. Flexirubin pigments are present. Catalase- and oxidase-positive. Nitrate reduction is positive. Chitin hydrolysis is positive; cellulose (Whatman No. 1) aesculin, glycogen and gelatin hydrolysis are negative. Other physiological reactions are given in Table 1 . The major fatty acids $(>7.5 \%$ of total) are iso- $\mathrm{C}_{15: 1}$, iso- $\mathrm{C}_{15: 0}, \mathrm{C}_{15: 0}$, iso- $\mathrm{C}_{15: 0} 3-\mathrm{OH}$, iso$\mathrm{C}_{17: 1} \omega 9 c$, and iso- $\mathrm{C}_{17: 0} 3-\mathrm{OH}$.

The type strain, WB $2.3-68^{\mathrm{T}} \quad\left(=\mathrm{DSM} \quad 21789^{\mathrm{T}}=\mathrm{CIP}\right.$ $\left.109868^{\mathrm{T}}\right)$, was isolated from a spring of Westerhöfer Bach, Westerhof, $40 \mathrm{~km}$ north of Göttingen, Germany. The DNA $\mathrm{G}+\mathrm{C}$ content of the type strain is $33.3 \mathrm{~mol} \%$.

\section{Description of Flavobacterium reichenbachii sp. nov.}

Flavobacterium reichenbachii (rei.chen.ba'chi.i. N.L. masc. gen. n. reichenbachii of Reichenbach, named after Hans Reichenbach, a famous German microbiologist, who pioneered the study of gliding bacteria).

Gram-staining-negative ( $\mathrm{KOH}$ and aminopeptidase reactions positive), aerobic and microaerobic rods $(1.0 \times 5.5-$ $8.0 \mu \mathrm{m})$. Does not grow anaerobically. Growth occurs between 6 and $30{ }^{\circ} \mathrm{C}$ with an optimal temperature between 20 and $26{ }^{\circ} \mathrm{C}$. Growth between 6 and $9{ }^{\circ} \mathrm{C}$ is sparse; no growth occurs below $6{ }^{\circ} \mathrm{C}$ or above $30{ }^{\circ} \mathrm{C}$. Growth occurs between pH 5.8 and 8.0 with an optimal $\mathrm{pH}$ of 6.2. Growth occurs at $\mathrm{NaCl}$ concentrations between 0 and $2 \%(\mathrm{w} / \mathrm{v})$, with optimal growth at $0 \%(\mathrm{w} / \mathrm{v}) \mathrm{NaCl}$. Gliding motility is present; flagella are absent. Colonies are golden yellow on R2A and CY agars, and orange-yellow on NA and TSA agars. Colonies are irregular with spreading and undulate margins, flat, smooth, translucent, shiny and butyrous. Colonies are 2.0-5.0 $\mathrm{mm}$ in diameter on R2A and NA agars and 1-2 mm in diameter on TSA and CY agars. Flexirubin pigments are present. Catalase- and oxidase-positive. Nitrate reduction is negative. Chitin, aesculin and gelatin hydrolysis is positive; cellulose (Whatman No. 1) and glycogen hydrolysis is negative. Other physiological reactions are given in Table 1. The major fatty acids ( $>7.5 \%$ of total) are $\mathrm{C}_{15: 0}$, iso- $\mathrm{C}_{15: 0}$, iso- $\mathrm{C}_{15: 0} 3-\mathrm{OH}$, iso- $\mathrm{C}_{17: 0} 3-\mathrm{OH}$ and summed feature 3 (comprising $\mathrm{C}_{16: 1} \omega 7 c$ and/or iso- $\mathrm{C}_{15: 0} 2-\mathrm{OH}$ ). 
The type strain, WB $3.2-61^{\mathrm{T}} \quad\left(=\mathrm{DSM} \quad 21791^{\mathrm{T}}=\mathrm{CIP}\right.$ $\left.109866^{\mathrm{T}}\right)$, was isolated from a spring of Westerhöfer Bach, Westerhof, $40 \mathrm{~km}$ north of Göttingen, Germany. The DNA $\mathrm{G}+\mathrm{C}$ content of the type strain is $34.3 \mathrm{~mol} \%$.

\section{Acknowledgements}

This project is part of the Research Unit 571 'Geobiology of Organoand Biofilms', funded by the German Research Foundation (Sta 184/ 19-2; DFG-FOR 571; publication 39). We thank Jean Euzéby for his advice on the nomenclature of the novel species. We thank Susanne Verbarg for the interpretation of physiological tests. The technical assistance of Gabriele Pötter (fatty acid analysis) is highly appreciated.

\section{References}

Barrow, G. I. \& Feltham, R. K. A. (1993). Cowan and Steel's Manual for Identification of Medical Bacteria, 3rd edn. Cambridge: Cambridge University Press.

Bernardet, J.-F., Segers, P., Vancanneyt, M., Berthe, F., Kersters, K. \& Vandamme, P. (1996). Cutting a Gordian knot: emended classification and description of the genus Flavobacterium, emended description of the family Flavobacteriaceae, and proposal of Flavobacterium hydatis nom. nov. (basonym, Cytophaga aquatilis Strohl and Tait 1978). Int J Syst Bacteriol 46, 128-148.

Bernardet, J. F., Nakagawa, Y. \& Holmes, B. (2002). Proposed minimal standards for describing new taxa of the family Flavobacteriaceae and emended description of the family. Int J Syst Evol Microbiol 52, 1049-1070.

Brambilla, E., Päuker, O., Cousin, S., Steiner, U., Reimer, A. \& Stackebrandt, E. (2007). High phylogenetic diversity of Flavobacterium spp. isolated from a hardwater creek, Harz Mountains, Germany. Org Divers Evol 7, 145-154.

Cousin, S., Päuker, O. \& Stackebrandt, E. (2007). Flavobacterium aquidurense sp. nov. and Flavobacterium hercynium sp. nov., from a hard-water creek. Int J Syst Evol Microbiol 57, 243-249.

Cousin, S., Brambilla, E., Yang, J. \& Stackebrandt, E. (2008). Culturable aerobic bacteria from the upstream region of a karst water rivulet. Int Microbiol 11, 91-100.

DSMZ (2001). Catalogue of Strains, 7th edn. Braunschweig, Germany: Deutsche Sammlung von Mikroorganismen und Zellkulturen GmbH. (http://www.dsmz.de/microorganisms/media_list.php).

Dye, D. W. (1968). A taxonomic study of the genus Erwinia. I. The 'Amylovora' group. N Z J Sci 11, 590-607.

Gerhardt, P., Murray, R. G. E., Costilow, R. N., Nester, E. W., Wood, W. A., Krieg, N. R. \& Phillips, G. B. (editors) (1981). Manual of Methods for General Bacteriology. Washington, DC: American Society for Microbiology.

Kämpfer, P. \& Kroppenstedt, R. M. (1996). Numerical analysis of fatty acid patterns of coryneform bacteria and related taxa. Can J Microbiol 42, 989-1005.
Mesbah, M., Premachandran, U. \& Whitman, W. B. (1989). Precise measurement of the $\mathrm{G}+\mathrm{C}$ content of deoxyribonucleic acid by highperformance liquid chromatography. Int J Syst Bacteriol 39, 159-167.

Miller, L. T. (1982). Single derivatization method for bacterial fatty acid methyl esters including hydroxy acids. J Clin Microbiol 16, 584586.

Muurholm, S., Cousin, S., Päuker, O., Brambilla, E. \& Stackebrandt, E. (2007). Pedobacter duraquae sp. nov., Pedobacter westerhofensis sp. nov., Pedobacter metabolipauper sp. nov., Pedobacter hartonius sp. nov. and Pedobacter steynii sp. nov., isolated from a hard-water rivulet. Int J Syst Evol Microbiol 57, 2221-2227.

Reichenbach, H. \& Dworkin, M. (1981a). The order Myxobacterales. In The Prokaryotes, pp. 328-355. Edited by M. Starr, H. Stolp, H. Trüper, A. Balows \& H. Schlegel. New York: Springer-Verlag.

Reichenbach, H. \& Dworkin, M. (1981b). The order Cytophagales (with addenda on the genera Herpetosiphon, Saprospira, and Flexithrix). In The Prokaryotes, pp. 356-379. Edited by M. Starr, H. Stolp, H. Trüper, A. Balows \& H. Schlegel. New York: SpringerVerlag.

Smibert, R. M. \& Krieg, N. R. (1994). Phenotypic characterization. In Methods for General and Molecular Bacteriology, pp. 607-654. Edited by P. Gerhardt, R. G. E. Murray, W. A. Wood \& N. R. Krieg. Washington, DC: American Society for Microbiology.

Stackebrandt, E. \& Ebers, J. (2006). Taxonomic parameters revisited: tarnished gold standards. Microbiol Today 33, 152-155.

Stackebrandt, E., Lang, E., Cousin, S., Päuker, O., Brambilla, E., Kroppenstedt, R. \& Lünsdorf, H. (2007). Deefgea rivuli gen. nov., sp. nov., a member of the class Betaproteobacteria. Int $J$ Syst Evol Microbiol 57, 639-645.

Stackebrandt, E., Frühling, F., Cousin, S., Brambilla, E., Lünsdorf, H. \& Verbarg, S. (2008). Methylibium subsaxonicum spec. nov., a betaproteobacterium isolated from a hardwater rivulet. Curr Microbiol 56, 298-305.

Tamaki, H., Hanada, S., Kamagata, Y., Nakamura, K., Nomura, N., Nakano, K. \& Matsumura, M. (2003). Flavobacterium limicola sp. nov., a psychrophilic, organic-polymer-degrading bacterium isolated from freshwater sediments. Int J Syst Evol Microbiol 53, 519-526.

Van Trappen, S., Mergaert, J. \& Swings, J. (2003). Flavobacterium gelidilacus sp. nov., isolated from microbial mats in Antarctic lakes. Int J Syst Evol Microbiol 53, 1241-1245.

Verbarg, S., Frühling, A., Cousin, S., Brambilla, E., Gronow, S., Lünsdorf, H. \& Stackebrandt, E. (2008). Biostraticola tofi gen. nov., spec. nov., a novel member of the family Enterobacteriaceae. Curr Microbiol 56, 603-608.

Wang, Z.-W., Liu, Y.-H., Dai, X., Wang, B.-J., Jiang, C.-Y. \& Liu, S.-J. (2006). Flavobacterium saliperosum sp. nov., isolated from freshwater lake sediment. Int J Syst Evol Microbiol 56, 439-442.

West, P. A. \& Colwell, R. R. (1984). Identification and classification of the Vibrionaceae - an overview. In Vibrios in the Environment, pp. 285-363. Edited by R. R. Colwell. New York: Wiley.

Zhu, F., Wang, S. \& Zhou, P. (2003). Flavobacterium xinjiangense sp. nov. and Flavobacterium omnivorum sp. nov., novel psychrophiles from the China No. 1 glacier. Int J Syst Evol Microbiol 53, 853-857. 